\title{
A Rare Case of Introral Lipoma in a 33 Months Old Child and a Review
}

\author{
Priyanka Agarwal*, Swati Patil and Minal Chaudhary
}

Department of Oral pathology, Sharad Pawar Dental College, Wardha, Maharashtra, India

\begin{abstract}
The lipoma presents as one of the common mesenchymal neoplasms however, in the oral and maxillofacial region its occurrence is less frequent, representing about $0.5 \%$ to $5 \%$ of all benign oral tumours. Most patients with lipomas are above 40 years of age or older, lipomas are uncommon in children and with gender distribution appearing to be approximately equal. Lipomas are usually asymptomatic until they grow to large size and may interfere with speech and mastication. Other benign connective tissue lesions such as granular cell tumor, neurofibroma, traumatic fibroma and salivary gland lesions (mucocele and mixed tumor) might be included in differential diagnosis. The purpose of this report is to present a rare case of a 2 year $\& 9$ months-old female patient with a histopathologically confirmed diagnosis of lipoma.
\end{abstract}

Keywords: Lipoma; Soft tissue neoplasm

\section{Introduction}

The various types of oral peripheral mesenchymal tumors are classified here as Furlong et al. [1]:

.Lipomas

-Myomas (rhabdomyomas and leiomyoma)

-Peripheral nerve tumors (neurofibroma, plexiform type of neurofibroma, schwannoma, traumatic neuroma)

By contrast, the morphologically intraoral lipomas can be classified as Rajendran et al. [2]:

-Diffuse form affecting the deeper tissues

Superficial form

Encapsulated form

Lipoma is defined as a benign, slow growing neoplasm composed of mature fat cells [2]. Lipomas are common tumors in the human body. Most patients with lipomas are above 40 years of age or older, lipomas are uncommon in children and with gender distribution appearing to be approximately equal [3]. The buccal mucosa and mucobuccal fold are the most common sites; followed by the tongue, floor of the mouth, and lip. In another report, the lip was the second most common site [4]. The size of tumor depends on the location but rarely exceeds 25 $\mathrm{mm}$ in diameter [5]. Lipomas are usually asymptomatic until they grow to large size and may interfere with speech and mastication [6,7]. Although malignant counterpart of this tumor, liposarcoma is another common soft tissue neoplasm, but its occurrence in oral cavity is rare [8].

\section{Case Report}

A 33 year old patient's mother complained that her child was reluctant to eat since 3 days. History revealed that the patient had vigorous habit of chewing toothbrush since 3 months for 3 hours daily. The parent's do not give any history of pain. The growth was initially small and reached to present size in a period of three months an extraoral examination revealed no specific abnormality. An intraoral examination, however, revealed a well-defined, pedunculated mass 2.5 $\mathrm{cm} \times 2 \mathrm{~cm}$ in size protruding from right buccal mucosa, extending from the distal aspect of 85 to the retro-molar region on that side. Color was reddish pink with slight yellow tint (Figures 1a and b). The peripheral region bore teeth indentations. On palpation the growth was nontender, soft in consistency, fluctuant and non emptiable. In keeping with the above findings, a provisional diagnosis of irritational fibroma was made, while pyo-genic granuloma, peripheral giant cell granuloma, and granular cell myoblastoma were considered as differential diagnoses. Routine blood and radiological tests were performed, but failed to reveal any significant findings and confirmed that blood parameters
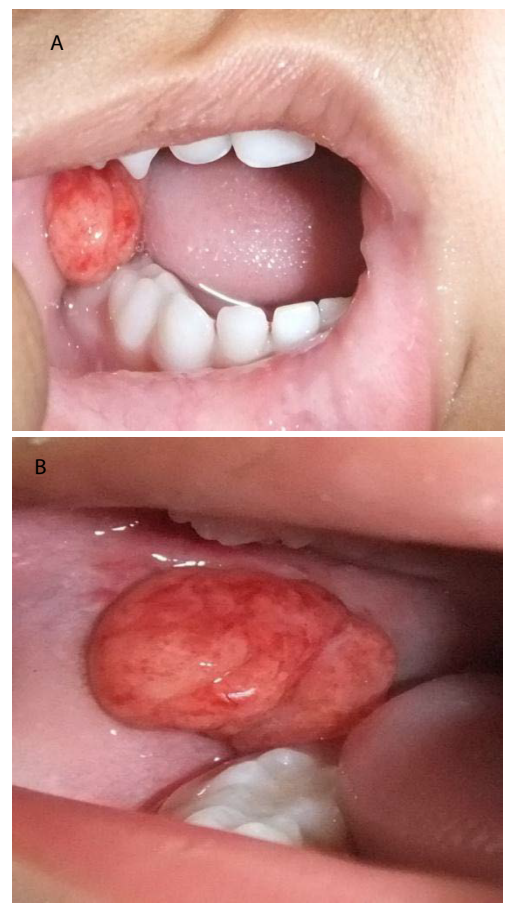

Figure 1: $a$ and $b$ Intraoral clinical photograph of the patient showing lesion.

*Corresponding author: Dr. Priyanka Agarwal, Assistant Professor, Department Of Oral Pathology, (S.P.D.C), Wardha, Maharashtra, India, Tel: +918237037027; E-mail: drpriyankaagarwal@gmail.com

Received February 17, 2014; Accepted February 23, 2014; Published February 25, 2014

Citation: Agarwal P, Patil S, Chaudhary M (2014) A Rare Case of Introral Lipoma in a 33 Months Old Child and a Review. Dentistry 4: 215. doi:10.4172/21611122.1000215

Copyright: ( 2014 Agarwal P, et al. This is an open-access article distributed under the terms of the Creative Commons Attribution License, which permits unrestricted use, distribution, and reproduction in any medium, provided the original author and source are credited. 
were within normal limits. The surface was smooth. Since there was no bony attachment at the base, the radiograph was not taken. Complete surgical excision was done. Macroscopically the resected mass was yellowish in color and soft in consistency.

Histopathological examination disclosed the presence of sheets of mature adipocytes containing clear cytoplasm and eccentric nucleus, with no evidence of cellular atypia or metaplasia. A thin fibrous capsule was also demonstrated (Figure 2). A distinct lobular arrangement of the cells was seen, with intervening fibrovascular connective tissue septa (Figure $2 \mathrm{a}$ and $\mathrm{b}$ ). Based on the histopathological features, the diagnosis of lipoma was made.

\section{Discussion}

Lipomas are the most common mesenchymal tumors especially in trunk and proximal portions of the extremities but they are rare tumors of oral cavity [9]. The first description of an oral lesion was provided by Roux in 1848. In his review of alveolar masses, Roux referred to the oral lesion as a "yellow epulis" [2]. Oral lipomas are usually soft, smooth-surfaced nodular masses that can be sessile or pedunculated.

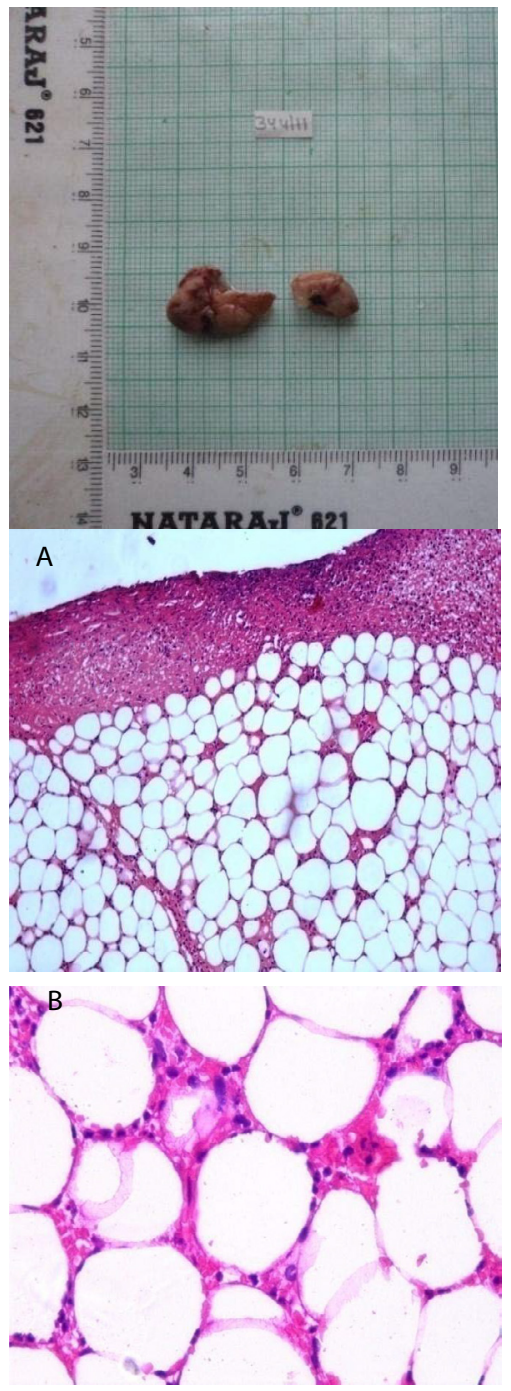

Figure 2: Photograph showing gross specimen.

a: Photomicrograph of histopathology of lesion under low power (10X) view. b: Photomicrograph of histopathology of lesion under high power (40X) view.
Typically the tumor is asymptomatic, and of a subtle or more obvious yellow hue. Oral lipomas more deeply rooted in the tissue may appear pink. Presented in this report is a case of intraoral lipoma in a thirty three month-old child. In referencing the literature to date, this type of case has been rarely documented. They are relatively uncommon in the oral cavity, representing about $0.5 \%$ to $5 \%$ of all benign oral tumors. Generally, their prevalence does not differ with gender, although a predilection for men has been reported [1] and they occur most often in patients older than 40 years $[10,11]$. In our case the patient is just 33 months old. Accounting for fifty percent of all cases, the buccal mucosa and buccal vestibule are the most common intraoral sites. Oral lipomas located on the buccal mucosa may not represent true tumors, but rather herniation of the buccal fat pad through the buccinators muscle. Such cases may occur subsequent to local trauma in young children or the surgical removal of third molars in older patients [12]. The lesion is usually non-tender, soft, and almost typically superficial in depth; but may infiltrate the muscle, become fixed to the surrounding tissue, and, therefore, unmovable. Deeply occurring lesions may produce only a slight surface elevation and may be well encapsulated, more diffuse, and less delineated than the superficial variety. This more diffuse form generates the clinical impression of a fluctuant tumor [13]. The consistency of the lesion varies from soft to firm depending on the quality and distribution of fatty tissue and the depth of the tumor [14]. Because of these clinical features, other lesions, such as oral dermoid and epidermoid cysts and oral lymphoepithelial cysts, must be considered in the differential diagnosis of oral lipomas [15]. Although oral lymphoepithelial cysts present as movable, painless submucosal nodules with a yellow or yellow-white colouration, they differ from oral lipomas in that the nodules are usually small at the time of diagnosis and usually occur in the first to third decade of life. Also, most oral lymphoepithelial cysts are found on the floor of the mouth, soft palate and mucosa of the pharyngeal tonsil [16] which is uncommon sites for oral lipomas. Oral dermoid and epidermoid cysts also present as submucous nodules and, typically, occur on the midline of the floor of the mouth [17]. However, oral dermoid and epidermoid cysts can occur in oral mucosa at other locations. Because an oral lipoma can occasionally present as a deep nodule with normal surface color, salivary gland tumours and benign mesenchymal neoplasms should also be included in the differential diagnosis [13]. Although oral lipomas are well-circumscribed soft-tissue lesions, rarely they give a radiographic impression of an intraosseous neoplasm within the mandibular canal. Microscopically, it is not possible to distinguish these lipomas from normal adipose tissue, despite their different metabolism (they are not used as an energy source as is normal adipose tissue), probably due to high lipoprotein lipase activity in neoplastic lipoma cells $[10,18]$. As oral lipomas are relatively rare, few large case series have been published in the English-language literature [1,10,19]. Though the etiology of lipoma is unknown, possible causes of which have been postulated are trauma, infection, chronic irritation, hormone alteration, metaphase of muscle cells, lipoblastic embryonic cell nest in origin [20]. The occurrence of multiple lipomas is associated with Cowden's syndrome or multiple hamartoma syndromes. This condition is either familial or sporadic and is associated with the predominantly postpubertal development of a variety of cutaneous, stromal and visceral neoplasms, resulting from mutations of the phosphatase and tensin homolog (PTEN) gene [21]. It can involve various organs, such as the skin, oral mucous membrane, thyroid, breast, ovaries and central nervous system. The most commonly affected extracutaneous sites are the breast and thyroid. Among the most common mucocutaneous lesions observed in people with this syndrome are small papular lesions in the palate and gingiva with up to $3 \mathrm{~mm}$ extension, which have a tendency to coalesce, 
papillomatous and verrucous lesions in the buccal mucosa, fissured tongue and cutaneous multiple lipomas [22]. Although multiple oral lipomas are rare in Cowden'ssyndrome, it should still be considered in the presence of multiple lipomas in the oral cavity.

Besides Cowden Syndrome, multiple lipomas may also be seen in neurofibromatosis, Gardner Syndrome, encephalocraniocutaneoud lipomatosis, multiple familial lipomatosis and Proteus Syndrome [14]. The histopathology remains the gold standard in the diagnosis of lipoma. Most oral lipomas are composed of mature fat cells that differ little in microscopic appearance from the normal fat cells that surround the tumor $[20,23]$. The cell varies slightly in shape and size and is somewhat larger, measuring upto $200 \mathrm{~nm}$ in diameter [24]. The tumor is usually well circumscribed and may appear as a thin fibrous capsule. A distinct lobular arrangement of the cells is also often seen.

All lipomas are vascularized, but under normal conditions, the vascular network is compressed by the distended lipocytes and is not clearly discernible. Lipomas are occasionally altered by the admixture of other mesenchymal elements that compromise an intrinsic part of the tumor. The most common element is fibrous connective tissue, which is often hyalinized and may or may not be associated with the capsule of fibrous septa [24]. Few lipomas show rearrangements of $12 q, 13 q$, and $6 \mathrm{p}$ chromosomes [2]. Because of the histologic similarity between normal adipose tissue and lipoma, accurate clinical and surgical information is very important in making a definitive diagnosis. Thus, a clinician sending a surgical specimen for microscopic analysis must provide the oral pathologist with all available clinical and surgical information [11,19]. The most common microscopic variant of oral lipomas is the fibrolipoma characterized by a significant fibrous component intermixed with lobules of fat cells. The other variants are $[2,23]$ :

-Angiolipoma - a mixture of mature fat cells and numerous small blood vessels.

-Spindle cell lipoma - variable amounts of uniform appearing spindle cells, typically in conjunction with a lipomatous component (i.e. when appearing with a mu- coid component, however, the impression of a myxoid lipoma is made).

.Pleomorphic lipoma - presence of spindle cells with bizarre, hyperchromatic giant cells.

-Intramuscular (infiltrating) lipoma - is more deeply situated and has an infiltrative growth pattern that extends between skeletal muscle bundles. When the spindle cells are of smooth muscle origin, the term "myolipoma" may be used, or "angiomyolipoma" when the smooth muscle appears to be derived from the walls of arterioles.

On rare occasions, isolated ductal or tubular adnexal structures are scattered throughout the fat lobules, in which case the term "adenolipoma" is applied. Peri- neural lipoma has also been reported. Rarely, chondroid or osseous metaplasia may be seen in a lipoma (i.e. osteolipoma, ossifying lipoma, chondroid lipoma, or ossifying chondromyxoid lipoma). Also rare have been reports of hibernoma (i.e. a benign neoplasm of brown fat) occurring in the oral/pharyngeal region.

The above-noted combinations of histological features are of no prognostic significance; although the clinical appearance of color and tissue consistency may vary in accordance with such combinations [25]. Moreover, the cells of oral lipomas appear to differ metabolically from normal fat cells despite being histologically similar. Therefore, a person subjected to a starvation diet will lose fat from normal fat deposits in the body, but not from the lipoma. Furthermore, when lipoprotein lipase activity is reduced, fatty acid pre- cursors are incorporated into lipoma fat at a more rapid rate than into normal fat [2].

In some cases, lipomas of the buccal mucosal region cannot be distinguished from a herniated buccal fat pad without a history of sudden onset post-trauma being nonevident. Lipomas of the oral and pharyngeal regions are, otherwise, simple to differentiate from other lesions; although spindle cell and pleomorphic types must be distinguished from liposarcoma. When metaplastic calcified tissue is present, the lesion may be confused with soft tissue chondroma or osteoma. Multiple head and neck lipomas have been observed in neurofibromatosis, Gardner's Syndrome, encephalocranio cutaneous lipomatosis, multiple familial lipomatosis, and proteus syndrome [2]. Lipoblastomatosis, a rarely-related lesion, is not a true neoplasm but rather a continuation of the normal process of fetal fat development carried on into postnatal life. It is clinically characterized in infants by the occurrence of solitary or multiple soft tissue masses developing at various sites, such as the buttock, chest, axilla or neck [26]. Most of these microscopic variations do not affect the prognosis, which are usually good [23]. The treatment of oral lipomas, including all the histologic variants, is simple surgical excision. No recurrence is observed [10]. Although the growth of oral lipomas is usually limited, they can reach great dimensions, interfering with speech and mastication [27] and reinforcing the need for excision.

\section{Conclusion}

Presented in this report is a case of intraoral lipoma in a thirty three-old child. In referencing the literature to date, this type of case has been rarely documented.

\section{References}

1. Furlong MA, Fanburg-Smith JC, Childers EL (2004) Lipoma of the oral and maxillofacial region: site and subclassification of 125 cases. Oral Surg Oral Med Oral Pathol Oral Radiol Endod 98: 441-450.

2. Rajendran R, Sivapathasundharam B (2009) Shafer's textbook of oral pathology. (6thEdn), Elsevier, India.

3. Waseem Ahmed, Muhammad Amin, Shafi Ullah (2009) Intra oral lipoma - an unusual site and size. PAFMJ 59: 137-139.

4. Venkateswarlu M, Geetha P, Srikanth M (2011) A rare case of intraoral lipoma in a six year-old child: a case report. Int J Oral Sci 3: 43-46.

5. Rapidis AD (1982) Lipoma of the oral cavity. Int J Oral Surg 11: 30-35

6. Keskin G, Ustundag E, Ercin C (2002) Multiple infiltrating lipomas of the tongue. $\mathrm{J}$ Laryngol Otol 116: 395-397.

7. Chidzonga MM, Mahomva L, Marimo C (2006) Gigantic tongue lipoma: a case report. Med Oral Pathol Oral Cir Bucal 11: 437-439.

8. Favia G, Maiorano E, Orsini G, Piattelli A (2001) Myxoid liposarcoma of the oral cavity with involvement of the periodontal tissues. J Clin Periodontol 28 109-112.

9. Nayak S, Nayak P (2011) Lipoma of the oral mucosa: a case report. Archives of Orofacial Sciences 6: 37-39.

10. Fregnani ER, Pires FR, Falzoni R, Lopes MA, Vargas PA (2003) Lipomas of the oral cavity: clinical findings, histological classification and proliferative activity of 46 cases. Int J Oral Maxillofac Surg 32: 49-53.

11. Epivatianos A, Markopoulos AK, Papanayotou P (2000) Benign tumors of adipose tissue of the oral cavity: a clinicopathologic study of 13 cases. J Oral Maxillofac Surg 58: 1113-1117.

12. Bandéca MC, de Pádua JM, Nadalin MR, Ozório JE, Silva-Sousa YT, et al (2007) Oral soft tissue lipomas: a case series. J Can Dent Assoc 73: 431-434.

13. Tan MS, Singh B (2004) Difficulties in diagnosing lesions in the floor of the mouth--report of two rare cases. Ann Acad Med Singapore 33: 72-76. 
Citation: Agarwal P, Patil S, Chaudhary M (2014) A Rare Case of Introral Lipoma in a 33 Months Old Child and a Review. Dentistry 4: 215. doi:10.4172/2161-1122.1000215

14. Kaur RP, Kler S, Bhullar A (2011) Intra-oral lipomas: Report of three cases. Dent Res J (Isfahan) Winter 8: 48-51.

15. Anavi Y, Gross M, Calderon S (1995) Disturbed lower denture stability dueto lipoma in the floor of the mouth. $\mathrm{J}$ Oral Rehabil 22: 83-85

16. Flaitz CM (2000) Oral lymphoepithelial cyst in a young child. Pediatr Dent 22: 422-423.

17. Longo F, Maremonti P, Mangone GM, De Maria G, Califano L (2003) Midline (dermoid) cysts of the floor of the mouth: report of 16 cases and review of surgical techniques. Plast Reconstr Surg 112: 1560-1565.

18. Solvonuk PF, Taylor GP, Hancock R, Wood WS, Frohlich J (1984) Correlation of morphologic and biochemical observations in human lipomas. Lab Invest 51: 469-474.

19. Seldin HM, Seldin SD, Rakower W, Jarrett WJ (1967) Lipomas of the oral cavity: report of 26cases. J Oral Surg 25: 270.

20. Greenberg MS, Glick M, Jonathan AS (2008) Burket's oral medicine. (11thedn). BC Decker, India.
21. Woodhouse JB, Delahunt B, English SF, Fraser HH, Ferguson MM (2005) Testicularlipomatosis in Cowden's syndrome. Mod Pathol 18: 1151-1156.

22. Solli P, Rossi G, Carbognani P, Spaggiari L, Gabrielli M, et al. (1999) Pulmonary abnormalities in Cowden's disease. J Cardiovasc Surg (Torino) 40: 753-755.

23. Neville BW, Damm DD, Allen CM, Bouquot JE (2009) Oral and maxillofacia pathology. ( $\left.3^{\text {rd }} e d n\right)$, Saunders, Philadelphia.

24. Weiss SW, Goldblum JR (2007) Enzinger and Weiss's Soft Tissue Tumors. $\left(5^{\text {th }}\right.$ edn $)$, Mosby Elesevier, Philadephia.

25. Wood NK, Goaz PW (1997) Differential diagnosis of oral \& maxillofacia regions. ( $5^{\text {th }}$ edn), Mosby, St Louis.

26. Darling MR, Daley TD (2005) Intraoral chondroid lipoma: a case report and immunohistochemical investigation. Oral Surg Oral Med Oral Pathol Ora Radiol Endod 99: 331-333

27. De Visscher JG (1982) Lipomas and fibrolipomas of the oral cavity. J Ora Maxillofac Surg 10: 177-181. 